\title{
International Education
}

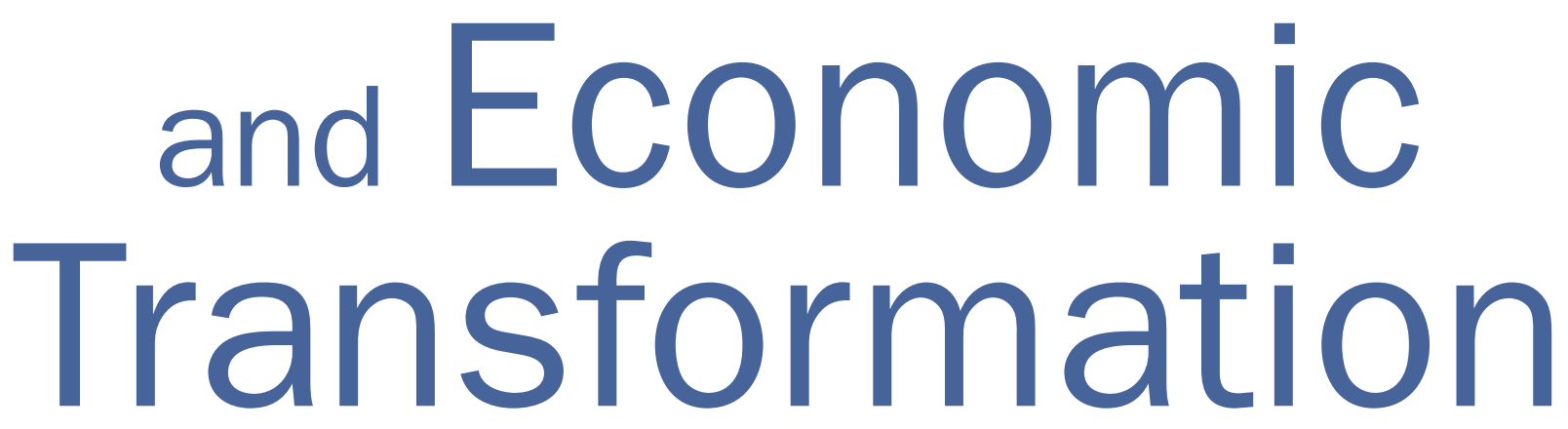

\section{Brett Parker}

This article sets out an analysis of the apparent and potential linkages between the international education (IE) sector, and the economic transformation agenda (ETA) for New Zealand's wider economy and society. It shows how the international education sector can help to drive New Zealand's shift into higher-value economic production.

The focus of the article is on international graduates from New Zealand's public and private tertiary providers, as they will have qualifications which can be recognised by employers. Moreover, their qualifications may be in demand and can help to increase workplace productivity.

Brett Parker is a Senior Policy Analyst in the Ministry of Education, focusing on issues associated with the international education sector. He has worked for several New Zealand central government agencies in policy and research roles. While at Te Puni Kōkiri he was responsible for a series of reports on the involvement of Māori in the economy, and in information technology. Email: Brett.Parker@minedu.govt.nz

\section{Key points}

The international education sector appears to have stabilised at around 91,000 enrolments of fee-paying students per year, with increasing numbers enrolled in schools and English language providers. As a key services export industry, the IE sector earned total fees revenue of $\$ 597$ million in 2007 , and provides a range of benefits for educational institutions and employers.

International education can be viewed as a specific application of the economic concept of human capital theory, and may aid in raising New Zealand's relatively low levels of labour productivity. The IE sector directly contributes to the ETA themes of 'growing globally competitive firms', 'innovative and productive workplaces' and 'Auckland as an internationally competitive city'. Its contributions are made primarily through the enhanced supply of skilled workers it potentially offers to New Zealand businesses, and, in particular, the social and educational enhancements the sector provides Auckland.

Further, an increase in the academic and research linkages between New Zealand and overseas universities shows significant scope to enhance the intellectual capital of staff and institutions, and provide economies of scale in undertaking research projects. The outcomes of these links can contribute to all the ETA themes.

There are a number of challenges to achieving the full potential of international education for the benefit of New Zealand's wider economy and society. While the government's international education agenda is intended to direct a wholeof-government approach to the development of this sector, the response of education providers to the challenges of internationalisation is critical. As well, the demands by employers for international graduates will be esssential to ensuring that the full potential economic value of international education can flow to New Zealand. 


\section{Background}

\section{Enrolments of international students}

The total enrolments of international students, across all education provider groups in New Zealand, rose by $348 \%$ from 28,340 in 1999 to 126,919 in 2002. From the market peak in 2002 there has been a $28 \%$ decline to 90,934 enrolments in 2007. The enrolments in particular provider groups, from the top five source countries, in 2007 are shown in Table 1.

It is notable that students from three North Asian countries (China, Japan and South Korea) made up 60\% of all international fee-paying enrolments with New Zealand providers. This proportion is a reduction from the peak of $73 \%$ that occurred in 2003. In 2007 Chinese students made up $46 \%$ of fee-paying international enrolments in the universities, and South Korean students made up 43\% of international enrolments in schools.

In 2007, most of the 90,934 international students were enrolled in the Auckland region (54\%), followed by Canterbury $(18 \%)$ and the Waikato and Wellington (6\% in each region).

\section{Enrolments in tertiary courses}

The single data return (SDR) system operated by the Ministry of Education allows for detailed extraction of data on the enrolments of international students in public and private tertiary education, according to their qualification level. Table 2 presents the trend in international enrolments since 2001 (note: due to classification differences, this data is not directly comparable with the Export Education Levy information stated in Table 1).

It is apparent that growth in international tertiary enrolments from 2001 to 2002 was driven by a 53\% increase in certificate enrolments; subsequently, growth until 2004 was based on a $203 \%$ increase in diploma and a $169 \%$ increase in undergraduate enrolments. Since the peak in 2002 there has been a 54\% decline in certificate enrolments, and (since 2004) a $40 \%$ fall in diploma enrolments.International postgraduate studies have slowly risen over time as a proportion of all international tertiary enrolments, at 9\% in 2000 and just over $12 \%$ in 2007 . There was a marked increase in international doctorate (PhD) enrolments from 2005 to 2007 (rising from 693 to 1,522 students); however, this was partly balanced by a reduction in international Masters enrolments, from 2,082 to 1,762. The increase in enrolments in $\mathrm{PhD}$ studies can largely be attributed to the 'domestic fees status for new international PhD students' policy introduced from 2006.

Table 3 shows there were substantial variations in the profile of qualifications enrolments according to the regional origins of international students. In 2007 the great majority of international tertiary students came from Asia (73\%), followed by Europe (10\%) and North America (7\%). Most Asian enrolments were in undergraduate courses (47\%), as were most North American enrolments (61\%). European enrolments had the highest proportion of participation in postgraduate courses $(28 \%)$.

A comparison with New Zealand tertiary enrolments in 2007 shows that, overall, international enrolments were much more focused on undergraduate studies $(45 \%$ as opposed to $26 \%$, and had a substantially higher proportion of postgraduate enrolments (12\% vs. $7 \%$ ). International tertiary students made up just over $8 \%$ of all tertiary students in New Zealand during 2007.

By comparison with the other 'main English-speaking destination countries' in the international education sector (i.e. Australia, the United Kingdom, Canada and the United States), New Zealand is unusual in recording a fall in international enrolments in higher education since 2004. Australia, the United Kingdom and Canada all increased their numbers of international students enrolled in higher education. The USA has experienced a slight decline in its high level of international enrolments, a result generally attributed to tighter immigration rules and security vetting (Verbik and Lasanowski, 2007).

\section{Economic impact}

In 2007 the international education sector (including schools and private training establishments) earned total fee revenue of $\$ 597$ million. The enrolment of 31,143 international feepaying students in the 28 state tertiary institutions contributed \$338 million in revenue to these providers, and the eight universities earned $\$ 274$ million of this amount. In 2006 international fees contributed about $13 \%$ of total university revenues of $\$ 2.3$ billion. These revenues are important, for example in supporting the development of facilities, in making some tertiary courses more viable through cross-subsidisation, and through a flow-on impact on other businesses through spending on services.

The economic contribution of the international education sector (i.e. international fee-paying students enrolled in New Zealand educational institutions) to the New Zealand economy has previously been calculated by Infometrics, based on 2004 data from the Export Education Levy (Stroombergen, 2006). This study estimated that the overall economic benefit - including tuition fees paid, living costs for students, and multiplier factors for the wider economy - amounted to $\$ 2.21$ billion in 2004 .

In a recent study of the economic impact of international education, Infometrics has estimated that the sector was worth \$2.1 billion to New Zealand in the 2007-2008 financial year. This study is based on a detailed survey of the expenditures reported by a randomly selected sample of international students. In addition, information from education-providers indicated that the value of their offshore education services was worth $\$ 70$ million in the period.

\section{Development of human capital}

International education can be viewed as a specific application of the economic concept of human capital theory. The assumption that human capital theory can be applied to the international education sector is based on the fact that international students who travel to New Zealand enrol with education providers. These enrolments lead to course completion/graduation by most students. The receipt 
Table 1: Top five source countries of fee-paying international students, 2007

\begin{tabular}{|c|c|c|c|c|c|c|}
\hline & Schools & Polytechnics & Universities & $\begin{array}{r}\text { Private \& } \\
\text { subsidiary* } \\
\text { providers }\end{array}$ & Totals & \%of total \\
\hline China & 2,106 & 3,614 & 9,648 & 9,408 & 24,776 & $27 \%$ \\
\hline South Korea & 6,579 & 866 & 1,252 & 8,806 & 17,503 & $19 \%$ \\
\hline Japan & 1,789 & 960 & 1,060 & 8,427 & 12,236 & $14 \%$ \\
\hline India & 73 & 1,180 & 768 & 1,715 & 3,736 & $4 \%$ \\
\hline Thailand & 793 & 148 & 337 & 1,691 & 2,969 & $3 \%$ \\
\hline All other countries & 3,867 & 3,239 & 8,071 & 14,537 & 29,714 & $33 \%$ \\
\hline Totals & 15,207 & 10,007 & 21,136 & 44,584 & 90,934 & $100 \%$ \\
\hline \%of total & $17 \%$ & $11 \%$ & $23 \%$ & $49 \%$ & $100 \%$ & \\
\hline
\end{tabular}

Source: Ministry of Education, Export Education Levy database.

* 'Subsidiary providers' are mainly the English-language foundation skills units run by the universities.

Table 2: International enrolments by qualification level

\begin{tabular}{|l|r|r|r|r|r|r|r|r|}
\hline & 2001 & 2002 & 2003 & 2004 & 2005 & 2006 & 2007 & $\begin{array}{r}\% \text { of total, } \\
2007\end{array}$ \\
\hline Certificate & 12,618 & 19,326 & 15,330 & 12,541 & 9,183 & 8,190 & 8,858 & $21 \%$ \\
Diploma & 5,119 & 9,356 & 14,425 & 15,539 & 13,704 & 10,736 & 9,344 & $22 \%$ \\
Undergraduate & 8,726 & 13,342 & 18,972 & 23,525 & 24,354 & 22,139 & 19,138 & $45 \%$ \\
Postgraduate & 1,940 & 2,480 & 3,631 & 4,368 & 4,242 & 4,437 & 5,154 & $12 \%$ \\
\hline Total enrolments & 28,403 & 44,504 & 52,358 & 55,973 & 51,483 & 45,502 & 42,494 & $100 \%$ \\
\hline Total students* & 26,236 & 40,824 & 47,115 & 50,441 & 47,365 & 42,651 & 39,942 & \\
\hline
\end{tabular}

Postgraduate totals include Honours degrees and postgraduate diplomas, Masters degrees and doctorates.

* Students who were enrolled at more than one qualification level have been counted in each level. Consequently, the sum of students is less than the sum of course enrolments.

Table 3: Tertiary enrolments by region and level, 2007

\begin{tabular}{|l|r|r|r|r|r|r|r|r|}
\hline & Africa & Asia & $\begin{array}{r}\text { Central } \\
\text { \& South } \\
\text { America }\end{array}$ & Europe & Middle East & $\begin{array}{r}\text { North } \\
\text { America }\end{array}$ & Pacific & New Zealand \\
\hline Certificate & 224 & 6,613 & 249 & 722 & 404 & 210 & 388 & 257,217 \\
Diploma & 62 & 7,134 & 78 & 840 & 60 & 575 & 579 & 62,748 \\
Undergraduate & 128 & 14,680 & 138 & 1,360 & 246 & 1,819 & 764 & 128,076 \\
Postgraduate & 112 & 2,962 & 141 & 1,140 & 137 & 394 & 267 & 33,915 \\
\hline Total & 526 & 31,389 & 606 & 4,062 & 847 & 2,998 & 1,998 & 481,956 \\
enrolments & & & & 568 & 3,873 & 784 & 2,974 & 1,918 \\
\hline Total students & 499 & 29,262 & $1 \%$ & $10 \%$ & $2 \%$ & 743,801 \\
\hline \%of students & $1 \%$ & $73 \%$ & & & & & $5 \%$ & $4 \%$ \\
\hline
\end{tabular}

of education services enhances the skills and marketability of the international students in New Zealand and overseas labour markets. Consequently, international graduates may be more likely to work in careers where their skills increase the productivity of the industries they are employed in.

Therefore, assuming that the provision of international education services enhances the human capital of the students implies that this increase in personal knowledge can enhance New Zealand's economic growth. This consequence may be seen as depending on whether the international students enter into employment in the domestic labour market, and increase the productivity of the industries in which they work. A similar consequence may result should (for example) the academic research completed by international $\mathrm{PhD}$ students help to raise the productivity of industries.

\section{New Zealand's labour productivity}

New Zealand is well known for having significantly lower levels of productivity than many other OECD countries, including Australia. This economic issue has direct implications for wage and salary levels (as pay is ultimately tied to productivity), and growth in New Zealand's national income. Figure 1 compares New Zealand's level of productivity (in terms of differences with respect to the United States, and the trend of GDP per hour worked) with the other countries in the OECD. It is apparent that New Zealand ranks in the bottom third of OEGD countries, significantly below Australia.

New Zealand's labour productivity grew $0.5 \%$ in the year ending March 2007. There has been subdued growth in labour productivity since 2000, averaging 1.1\% annually. Labour input has grown at a record rate of $2.2 \%$ annually since 2000, 


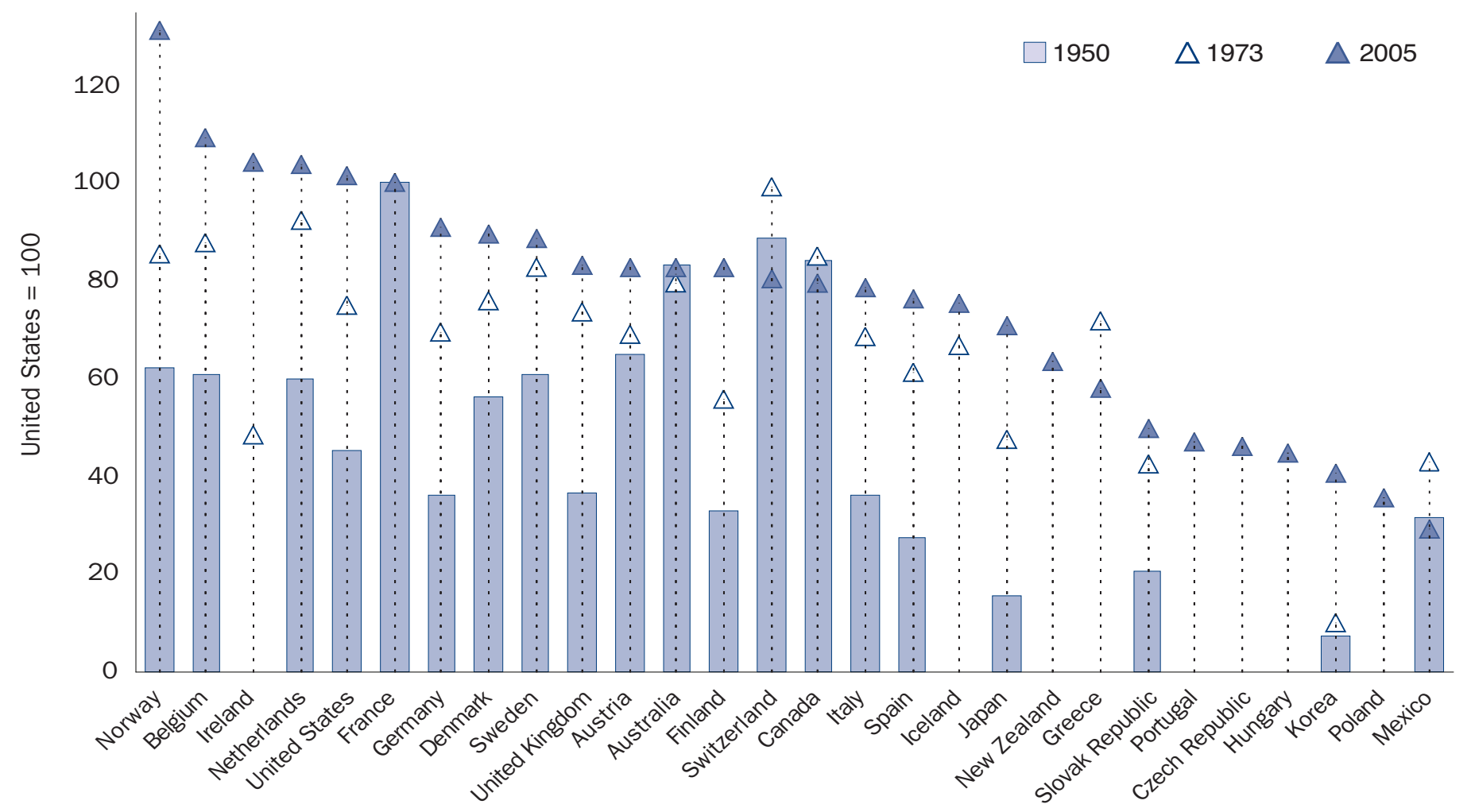

Source: OECD

while growth in output (real GDP) averaged 3.3\%, which is stronger than the 1978-2007 annual average of $2.6 \%$. This combination resulted in slower growth in labour productivity than the overall annual average of 2.0\% from 1978 to 2007.

The slow growth in labour productivity and incomes is a major policy concern, given the low levels of unemployment in New Zealand and the expansion of policies by other countries to attract skilled labour to help drive their economic growth.

\section{The global 'war for talent'}

According to the OECD (OECD, 2007), many countries are undertaking reforms of their immigration and higher education systems in order to attract and retain welleducated and skilled workers. These changes are being driven by the continuing pressures of declining fertility and ageing demographics in many developed countries, with the consequent need to replace increasing numbers of retirees; and by the surging demand for skilled human capital by the expanding industries of several developing nations. In some countries, the private sector is taking more account of the resulting implications of demographics for business performance (e.g. the annual 'Demographic Fitness Index' developed by the Adecco Institute of Switzerland).

The need for New Zealand to introduce policies to make the nation more attractive to skilled people, both domestic and international, has been highlighted by increasing and publicised demand for workers in a wide range of occupations and professions. There has been extensive debate around the terms 'brain drain', 'brain exchange' or possibly 'brain gain' in relation to New Zealand's comparatively large diaspora of people living overseas (Statistics New Zealand, 2008) and significant inward migration flows. A recent report has examined the contribution of migration to skill changes in New Zealand (Newell and Perry, 2006).

Internationally, policies to attract skilled people include the promotion of higher education to students from other nations, the expanded provision of English-language university courses, 'points' systems to attract skilled and educated migrants, liberalised work visa rules, and programmes to entice back successful expatriates.

In recent years New Zealand has implemented relevant versions of all these policies. In particular, the Department of Labour is facilitating a workplace productivity agenda (see www.dol.govt.nz/workplaceproductivity), as part of the 'innovative and productive workplaces' theme of the ETA. One of the productivity drivers for this project is 'investing in people and skills'. A similar rationale is behind the current immigration policy to attract skilled migrants, and workers with skills in areas of shortage, to New Zealand (www. immigration.govt.nz). The economic case for the 'skilled migrant' category is based on an assumption that migrants (and returning citizens) with marketable skills are able to enter employment and so help to increase the output and productivity of New Zealand's industries.

A number of new entrants in the international education market are attracting students away from the established 'main English-speaking destination countries' of the USA, United Kingdom, Australia, Canada and New Zealand (ranked in order of their international enrolments in higher education). 
These new entrants include The Netherlands, Malaysia and South Africa, along with specific higher education developments in Dubai and Singapore. China is also known to be greatly increasing its investment in higher education facilities, which may reduce demand for international education by Chinese students.

\section{How international education can assist economic transformation \\ The economic transformation agenda}

The economic transformation agenda (ETA) seeks to progress New Zealand to a high-income, knowledge-based market economy, which is both innovative and creative and provides a unique quality of life to all New Zealanders. Economic transformation is a cross-departmental effort led by the Ministry for Economic Development. It comprises five themes: 'growing globally competitive firms', 'world class infrastructure', 'innovative and productive workplaces', 'Auckland as an internationally competitive city' and 'environmental sustainability'. The more detailed explanations for the five themes are set out on the website of the Ministry for Economic Development (www.med. govt.nz).

The IE sector contributes directly (through fees and other revenue) and indirectly to the ETA themes of 'growing globally competitive firms', 'innovative and productive workplaces' and 'Auckland as an internationally competitive city'. The latter contribution is implicit in the fact that $54 \%$ of all international enrolments are with education providers located in the Auckland region.

The known direct economic impacts have been stated above. The indirect economic contributions are made through attracting skilled people to New Zealand, and increasing the availability of a pool of international graduates available for employment. Internationalisation policy is also intended to aid in developing New Zealand universities and tertiary providers as globally competitive institutions, and assist the expansion of university research linkages with institutions in other countries, leading to the generation and channelling of new knowledge and intellectual property.

\section{Attracting skilled people}

International education can be seen as contributing to the ETA themes due to the development of a labour pool of skilled and qualified international graduates. These tertiary graduates may have higher levels of intercultural competencies, including fluency in the languages of our key trading partners (notably Mandarin, Japanese and Spanish).

The main labour market benefits of the international education sector can be expected to come through an increase in the numbers of highly educated and skilled people resident in New Zealand, leading to a greater 'thickness' of the market for skills - potentially leading to better matching between job-seekers and employers; and improved international connections, both when the graduates return to their home country and if they become resident in New Zealand.

A 2007 survey undertaken for the Ministry of Education shows that a high proportion of international students intend to seek employment/permanent residency in New Zealand (Ministry of Education, 2007). Just under half of the tertiary students surveyed $(48 \%)$ stated that they intended to work in New Zealand once they had completed their studies. Students studying sciences, medicine and education are more likely to seek permanent residence in New Zealand.

Another 2007 study by the Department of Labour found that New Zealand is relatively successful in attracting and retaining international students (Merwood, 2007). The majority of students who subsequently take up permanent residence in New Zealand do so as skilled or business migrants. The research also showed that the pathways to work and residence can be complex, and encompass many points of transition.

A notable example of a policy intended to attract top international scholars has been the introduction of domestic fees for new international $\mathrm{PhD}$ students. This initiative has

\begin{abstract}
been markedly successful in increasing the number of these top students in New Zealand: a 56\% increase in $\mathrm{PhD}$ enrolments was recorded in 2006, and a further $40 \%$ rise in 2007 to a total of 1,522 . The future output of $\mathrm{PhD}$ graduates could be encouraged to seek work in New Zealand universities, companies and research institutions.
\end{abstract}

\section{Growing globally competitive firms}

In the public policies of many developed nations, universities are increasingly viewed as important contributors to 'innovation systems' and economic development. These benefits are seen in the skilled researchers they employ, the students they educate and the commercial benefits of their linkages to businesses and their wider communities. ${ }^{1}$

There is significant potential to further develop New Zealand's universities as globally competitive institutions. To do so, the international activities that generate new revenue streams need to be undertaken in a sustainable commercial fashion. Of the eight universities, two (Auckland and Otago) each have equity worth over $\$ 1$ billion, and revenues over $\$ 400$ million for 2006. These two universities are also New Zealand's highest graded institutions in the world university rankings compiled by Shanghai's Jiao Tong University and Times Higher Education/QS. 


\section{Tertiary research and teaching linkages}

New Zealand's tertiary institutions and Crown research institutes all contribute to national economic development. There is scope to increase their international connections and revenue generation, and agencies (particularly New Zealand Trade and Enterprise) are assisting them to develop their capability to export knowledge-based services.

An increase in the formal academic and research linkages between New Zealand and overseas universities offers significant scope to enhance the intellectual capital of staff and institutions, and provide economies of scale in undertaking research projects. There are opportunities to build linkages in areas which might contribute to New Zealand's research priorities, and the outcomes of these links can contribute to all the ETA themes.

International research linkages by New Zealand tertiary education providers increased dramatically between 1998 and 2005 - coinciding with the very marked increase in in place to help generate information on the annual numbers of international graduates who remain in New Zealand and gain employment.

Research into the potential for social and education connections with international students has previously been supported by the Asia New Zealand Foundation (Berno and Ward, 2003), and the Education New Zealand Trust has recently commissioned Infometrics to survey the economic impact of international students, a study which will also investigate their tourism connections.

The Department of Labour's 'Longitudinal Immigration Survey: New Zealand' has scope to examine outcomes for former students compared to other skilled migrants. The department is also undertaking a study on transitions to residence, taking a cohort of permanent residents (who were formerly work/student permit holders) and questioning them about their employment activities and what were some of their decisions leading to residence.

\section{A confidential study undertaken for the lead sector body, the Education New Zealand Trust, found that the rate of university re-investment of revenues from their international students was markedly below equivalent levels for Australian universities.}

\section{Challenges}

The International Education Agenda: a strategy for 2007-2012 (www.minedu.govt.nz) sets out the government's vision and strategy for international education in New Zealand. The agenda is a statement by nine key government agencies involved in international education. It sets out the government's objectives and priorities for the sector, and outlines the complementary roles government and providers have in achieving the objectives. The agenda sits alongside the industry strategy for international education, developed by

international enrolments experienced by the universities (McInnes, Peacock and Catherwood, 2006). Among tertiary education institutions there was a major increase of almost 400 co-operation arrangements with foreign counterparts to a total of 547 in 2005, of which 505 were in the eight universities. About half of those were at the University of Auckland. These agreements involved 449 overseas institutions. In addition, there were 145 international research ventures of a commercial nature, concentrated at the University of Auckland (73) and the University of Otago (58).

There was also a very sizeable increase in the number of research centres with international research links, from 46 in 1998 to 261 in 2005. In broad terms, the level of activity associated with the internationalisation of research has apparently quadrupled since 1998.

\section{Research questions}

The connections noted between the enrolments of international students and subsequent improvements in labour productivity are largely assumptions, as accurate survey or administrative data on the job search and employment experiences of international students and graduates is currently lacking. A number of studies are now

\section{education New Zealand as the lead sector body.}

The four goals of the international education agenda are: New Zealand students are equipped to thrive in an interconnected world; international students are enriched by their education and living experiences in New Zealand; New Zealand providers are strengthened academically and financially; and New Zealand receives wider economic and social benefits.

While the agenda, and a number of policyinitiatives funded from recent budgets, are intended to support international education, the key drivers for sector development remain the individual decisions of some 1,200 public and private education providers. There are limited policy levers which can be applied to guide decisions to invest in internationalisation, and so the need is for institutions themselves to recognise the merits and benefits of increasing their activities in this area.

However, there are indications that New Zealand tertiary institutions are not assigning a high priority to internationalisation efforts. A confidential study undertaken for the lead sector body, the Education New Zealand Trust, found that the rate of university re-investment of revenues from their international students was markedly below equivalent levels for Australian universities. In policy terms, most of the 2007 investment plans for tertiary institutions, which were 
agreed to with the Tertiary Education Commission, did not contain notable references to international activities (with the exception of the plan for the University of Auckland).

New Zealand tertiary providers are currently much less active in providing offshore joint ventures and programmes than are, for example, British and Australian higher education institutions. While there is significant potential for growth in offshore provision, there are also real risks in terms of stretching management capability, the possibility of commercial failure and the consequent potential harm to New Zealand's wider education reputation.

It is probable that the peak level of international enrolments New Zealand experienced in 2003-2004 will not be repeated, given the particular nature of demand from Chinese students at the time. Consequently, the profile of international education is likely to have declined in importance for many institutions. Criticism has previously been made of the relatively strong focus on 'export education' by Australian, New Zealand and UK universities, an implication being that a largely revenue-driven model may not be sustainable in the longer term (see, for example, Knight, 1999).
A further concern with respect to achieving the full benefits of international education relates to attitudes of New Zealand businesses and organisations to employing international graduates. A number of past studies have highlighted concerns that employers are less willing to hire people from other countries, particularly people with qualifications which are not recognised in New Zealand (Grealish, 2008).

Given the skills shortages already apparent in the domestic labour market, and increasing demand for workers in other countries, a reluctance to employ international graduates could impose significant constraints on the human capital available to New Zealand employers. Such a result would be likely to seriously limit the wider economic benefits that international education can offer to New Zealand.

\footnotetext{
1 Examples of this analysis are "Engines of economic growth - the economic impact of Boston's eight research universities on the metropolitan Boston area', www.masscolleges. org; and 'Research-intensive universities as engines for the "'Europe of Knowledge"', League of European Research Universities, www.leru.org.
}

\section{References}

Berno, T. and C. Ward (2003) 'Cross-cultural and education adaptation of Asian students', Asia New Zealand Foundation, www.asianz.org.nz

Grealish, D. (2008) 'Immigration research programme: summary of findings 2007', Wellington: Department of Labour, www. dol.govt.nz

Knight, J. (1999) 'Quality and internationalisation in higher education', OECD, www.oecd.org

Mclnnis, C., R. Peacock and V. Catherwood (2006) 'Internationalisation in New Zealand tertiary education organisations', Ministry of Education, www.minedu.govt.nz
Merwood, P (2007) 'International students: studying and staying on in New Zealand', Department of Labour, www.dol.govt.nz

Ministry of Education (2007) 'The experiences of international students in New Zealand: report on the results of the national survey 2007', www.minedu.govt.nz

Newell, J. and M. Perry (2006) Trends in the Contribution of Tertiary Education to the Accumulation of Educational Capital in New Zealand: 1981 to 2001, report prepared for the Ministry of Education, Wellington: Monitoring and Evaluation Research Associates Ltd OECD (2007) 'Gaining from migration: towards a new mobility system', http://www.oecd.org
Statistics New Zealand (2008) 'Permanent and long-term departure rates of New Zealand citizens', www.stats.govt.nz

Stroombergen, A. (2006) The Economic Impact of Foreign Fee-Paying Students, report prepared for the Ministry of Education, Wellington: Infometrics Ltd, www.minedu. govt.nz

Verbik, L. and V. Lasanowski (2007) 'International student mobility: patterns and trends', Observatory on Borderless Higher Education, www.obhe.ac.uk 